\title{
4 How The US Congress Knows and Evades Knowing About Anthropogenic Climate Change: The Record Created in Committee Hearings, 2004-2016
}

\begin{abstract}
Anthropogenic climate change is a global problem requiring international coordination, depending on shared knowledge leading to shared formulation of problems, solutions, and mechanisms of action. Each nation's governmental bodies, however, have their own processes of admitting and evaluating knowledge, defining interests, deliberating, and coming to commitments. This essay examines the transcripts of relevant committee hearings from the $109^{\text {th }}$ to the $115^{\text {th }}$ Congresses to consider what the US Houses of Congress come to know or not know about climate change in their deliberations, within the structures of their procedures and regulations by which discussion is controlled. Committee hearings are an important activity system with corresponding genres for putting on the record information bearing on deliberation and decision making, but what goes on the record in the hearing transcript genre is limited by the questions asked and the witnesses called, both controlled by the committee chair from the majority party. Depending on the party in control and the purview of each committee, fundamental issues may or may not be addressed and members of Congress may or may not be required to go on the record with their views of climate change. Often members of the party opposed to climate change action may nonetheless act in ways consonant with anthropogenic climate change belief, as long as they do not directly address climate change knowledge. On the other hand, this arrangement offers chairs and other high-profile members of certain committees to advance oppositional agendas. Members of the minority party have limited scope to put knowledge relevant to their own positions on the record.
\end{abstract}

\subsection{The Complexity of Congressional Deliberation}

In order to understand the context of the control of knowledge within the US Congress and thus the limited attention given to anthropogenic climate change, we need first rehearse some basics of US governance. The United States has separation of powers both at the national level, with divisions among executive, legislative, and judicial branches, and between federal and state jurisdictions. Further, Congress is divided into the Senate and the House of Representatives. These divisions of power mitigate against a unified, stable response to anthropogenic climate change, which would require Congressional approval and Presidential signature. Because of political divisions at the Federal level, the Paris Agreement negotiated by the Executive Branch was never submitted as a treaty for Congressional approval, and only stood 
as an executive commitment of President Obama's administration. President Trump has since announced his attention to withdraw from the Paris Agreement. Because of separation of powers between federal and state governance, however, some states, cities, and other jurisdictions have stated their intention to abide by the agreement (Tabuchi \& Fountain, 2017).

A core challenge in gaining unified national US commitment to the Paris Agreement or any major international climate agreement has been gaining the agreement of Congress which must approve treaties and laws. Despite the prominence of global climate issues, the scientific consensus, IPCC reports, international meetings and even the Paris accord, and despite extensive hearings on the issue in both houses, Congress has passed no major climate legislation or international agreement, the authoritative formal genres by which action is taken in the legal system. This failure of legislative action affects not only the United States, but all nations attempting coordinated action. This lack of action on the part of Congress, therefore, is a serious puzzle, leaving us to ask if the House and Senate don't know there is a problem. In an institutional sense, this is so, as the following analysis shows.

In contrast, the executive branch, despite differences among officials, can appear unified under the direction of the President, with internal processes and divisions hidden from view. This can result in rapid policy reversals (and changes in administrative genres) with the change in administrations, as has happened between Presidents Obama and Trump with respect to the Paris Agreement. Congress is a different matter, with 435 voting representatives and 100 senators, divided into two parties, with multiple factions and individual interests, each responsive to multiple pressures. Further, deliberations are somewhat transparent with debate, hearings, reports, and votes published regularly.

As a deliberative body Congress has multiple procedures to gather facts to determine what areas under their charge warrant legislative action (see Krehbiel, 1991 for the classic study of the role of information in legislative bodies). Congress regularly receives reports from the Congressional Research Service, the US General Accounting Office, the Congressional Budget Office and other agencies in the legislative and executive branches. Further, each Senator and Representative has staff to gather and select facts they need. Further the Senate and House have organized committees with staffs, procedures, rules, and powers to gather information and expert opinion. Among these procedures are open public hearings, which invite documents and witnesses. The hearings are then transcribed and made public. Among all the information procedures, these hearings and their published transcripts create the most public face of the knowledge commitments of each member of Congress within a deliberative setting, the place they are seen to be engaged in fact-finding.

From this simple, even naive, view hearings could be seen to provide the knowledge upon which rational decisions are made, in the same way that evidence enters into a court through specific rules and procedures (Bazerman, 2009). From a rhetorical perspective (Aristotle, 1991), Congress engages in deliberative rhetoric. From 
activity theory (Russell, 1997) and genre perspectives (Bazerman, 1994; Miller, 1984), Congress is an activity system with the object of legislation, where evidence and reasoning would be represented and brought to bear on issues within the genres of deliberation. From a theory of organizational knowledge (Krehbiel, 1991; Nonaka, 1994), the record of hearings indicates what any Congress knows, how it learns, and how it goes about making decisions.

Congress, however, is more than a deliberative body; it is a legal, representative, governmental, and political body. As a legal body it is accountable to rules overseeing its actions. As a representative body each member is accountable to voting constituents, including beliefs, sentiments, and interests of those constituents. As a governmental body, it acts within a system of checks and balances within the separation of powers. As part of a political body, Congress members are accountable to voting constituents and other stakeholders, in order to gain reelection every two years for the House and every six years for the Senate (Arnold, 1990; Mayhew, 2004). Within current political practice, stakeholders include corporations, interest groups, and media who can provide financial, publicity, or other reelection supports, whether or not they are located within any particular Congressional district.

Further, electoral politics are organized through political parties that also provide internal structure within Congress. Party members caucus together, and party leaderships control positions on committees and other privileges that can advance or impede individual careers. In recent decades partisan strategies have diminished deliberative functions and bipartisan committee staffs in order to increase the roles of party leadership (Mann \& Ornstein, 2006).

Despite partisan activity systems that control the operations of both houses and that influence the operations of committees as activity systems, members of Congress have a stake in appearing deliberative in the best interests of the nation and their constituencies. Accordingly, they seek placement and seniority on committees of value to their constituencies (Weingast \& Marshall, 1988). While we cannot assume a simple deliberative function to the knowledge presented in congressional hearings and memorialized in the genre of public transcripts of hearings, those documents do provide a record of what an overtly deliberative body claims to know as a rationale for action or inaction and a record for accountability. Understanding the processes by which knowledge appears on the record and who controls these processes can illuminate the rhetorical dynamics of Congressional decision-making and give guidance in how to interpret and perhaps influence knowledge that guides legislation. 


\subsection{Knowledge in Hearings: Theories of Genre, Stasis, and Relevance}

Knowledge presented in hearings is constrained and directed by the genres of hearings with associated social situations, the questions or stases defined within the genres, and what is considered relevant to the particular stases of the hearings.

Genre theory identifies that each genre within its appropriate social situation (Miller, 1984; Russell, 1997) activates expectations of information appropriate to the genre, which an effective text would need to address (Bazerman, 2013; Bazerman \& Self, 2017; Burke, 1931; Miller \& Selzer, 1985). Congressional committee hearings genres include confirmation, legislative (including budgetary), oversight, and investigative, usually held in Washington with full membership of the committee or subcommittee (with absences, noted and unnoted). The printed hearing transcript is prefaced with membership of the committee (and subcommittee where appropriate), table of contents, and sometimes the call and agenda for the meeting. The hearing proper opens with a statement by the committee or subcommittee chair that defines the purposes of the hearing, sets the rules for statements and questioning, and perhaps anticipates the witnesses and their testimony. The chair describes the value of the session and perhaps takes a position. The ranking minority member then typically makes a statement. Other members of the committee also usually have the option of making a statement. Written statements supplementing oral comments or from absent members may also be added to the printed transcript. Witness statements and responses to oral and written questions are also in the printed transcript.

Within these larger generic expectations, the chair defines the specific question for the hearing. In classical rhetoric the framing of this question to be discussed is called the stasis. The stasis is the issue that a rhetor chooses to take a stand on and generate arguments about. The traditional stases are fact, definition, value, and procedure/jurisdiction. The classical four stases are most clearly seen in legal contexts for which they were developed (Cicero, 1949; Quintillian, 1920). A defense that has compelling evidence that the accused cannot have done the alleged act wants to argue the facts. If, however, the evidence is weak, the defense may argue on the definition of the act, claiming the alleged murder was actually self-defense. Failing that, the defense might argue value, admitting the crime, but saying the act was a good, such as the assassination of a brutal dictator. A last resort is to say the trial is not being carried out properly or the case does not belong in the jurisdiction of the court, and thus the judgment is illegitimate. These stases may operate in non-judicial settings and not follow sequentially but rather be invoked in relation to audience, domain, or genre (Fahnestock \& Secor, 1988). In Congressional budgetary hearings the issue of value or jurisdictional legitimacy of programs may be the primary question rather than the program's existence or the underlying conditions addressed by the program. Apart from the four classical stases, the more general idea of stasis helps us identify the issue being held constant or stable for argument. 
With hearings, the stasis is frequently revealed in the title of the hearing, along with a stance and burden of proof, as in the March 23, 2007 hearing of the Investigations and Oversight Subcommittee of the House Science and Technology Committee of the $110^{\text {th }}$ Congress, "Shaping the Message, Distorting the Science: Media Strategies to Influence Science Policy.” The opening statement by the subcommittee chair Representative Brad Miller then further defines the issue to be considered, the stance embedded in the stasis, and perhaps the weight of the evidence to be presented by witnesses, as in the latter

The topic of today's hearing is a consorted effort by opponents of measures to reduce greenhouse gas emissions, to bully scientific facts into submission, and, under intense pressure, the facts about global warming caved in and proved much more elastic [...] According to the testimony we will hear today, since 2001, the Bush Administration has been part of the effort to manipulate the public debate about climate change [...]

The opening statement for the minority then identifies the argumentative stance and particular stasis within the larger stasis to be taken by the minority. In this case Representative Dana Rohrabacher diverts the stasis of whether science was suppressed to whether there in fact is a scientific consensus to be suppressed.

Thank you very much, Mr. Chairman. Let me note if there was ever a case of the pot calling the kettle black, this hearing is that example. For Pete's sakes, we have had tens of billions of dollars over the last 20 years spent on climate change research, and in the last 10 years or so, it may have been 15 years, there is ample evidence, and I will be submitting these quotes for the record, of prominent scientists who have been complaining that they have not been able to get grants if they voice skepticism about the global warming "consensus".

With the choice of witnesses under the control of the majority chair, the minority can assert their views and facts only in their statements, questions, and supplementary documents or perhaps through one or more courtesy witnesses granted by the chair. The chair's power to set the stasis is recognized by the committee members of both parties and some witnesses who often thank the chair for holding a hearing on a particular topic, even when presenting an opposing position. Occasionally as in the case above, a minority member may instead complain about the stasis in order to undermine the kind of evidence that would be collected under it. Both thanks and complaints recognize the power of the stasis to control the information presented as relevant.

Sperber and Wilson $(1986,1995)$ theorize relevance cognitively as what an auditor or reader perceives as necessary to understand a message, tempered by the cognitive effort necessary to process the input. These informational needs and expectations oblige a statement maker to anticipate and provide the information expected by the auditor in as unencumbered way as possible (Grice, 1975), minimizing the cognitive load. While relevance theory is framed in cognitive terms, genre and stasis theories provide a social framing for relevance within organized institutional, political, and 
rhetorical settings. In Congressional hearings relevance at the largest level is defined by the overall purposes and rules of the committee, enforced by the chair and the specific genre, such as a budgetary hearing. The framing question or stasis of the hearing further specifies relevance. Each speaker then frames a particular point of response, offering a more local stasis. Within these stases we will examine how the facts of climate change are relevantly placed on the record, or contested, or evaded. We will also examine how other facts related to other stases are made relevant to the record.

\subsection{The Committee System, Hearings, and Records of Hearing}

While committees have existed since the early years of the Congress, they have become increasingly autonomous under the control of the majority party committee chairs. The committee chair has authority over what business and issues will be placed before the committee, which hearings will be held, how they are framed, and what witnesses appear, although the chair may consult with the ranking minority member or other committee members. Certain kinds of hearings require testimony of particular witnesses, such as confirmation hearings where the candidate appears, or budget and oversight hearings, where the relevant agency head appears. Also often some witnesses are granted the minority as a courtesy.

The basic procedures of committees have been set out in official governmental documents and a few descriptive studies (Galloway, 1959, 1961) along with the career strategies pursued by congressmen in seeking placement on committees (Weingast \& Marshall, 1988). Fenno (1973) and Deering and Smith (1997) have studied in greater detail the functions and operations of committees. None of these, however, have given more than passing mention of hearings, nor have they examined how hearings work and what they accomplish, nor the kinds of knowledge they produce with what consequences for Congressional action. Neither has more recent scholarship taken up these issues, despite hearings providing evidence in the study of other topics or specific legislative initiatives. The current study, in the course of studying how evidence of anthropogenic climate change becomes consequential for Congrssional deliberations, is a step toward unpacking how hearings are organized and with what effect in creating institutional knowledge. Perhaps the findings here will revive an interest in the workings and reform of these deliberative processes.

This study is based on a corpus of hearing transcripts as made available at the Government Publishing Office website. ${ }^{1}$ These hearing transcripts are not verbatim

1 In the early years of the republic, partial records of congressional deliberations were published in The Debates and Proceedings in the Congress of the United States (1789-1824), the Register of Debates in Congress (1824-1837), or the Congressional Globe (1833-1873). But in 1873 the Congressional Record began providing a fuller transcript of debate in both the house floor and committees (Mantel, 1959). 
reports, because they include editing, emendations, written comments, extensions, and additions (Mantel, 1959). Nonetheless, the printed document stands as the permanent record of the deliberations. This study does not look at the political or backroom processes behind the framing of topics or selection of witnesses, nor on the work of the staff members in arranging for and preparing witnesses. Rather this study examines all committee hearing transcripts in both houses of Congress from the $109^{\text {th }}$ Congress starting in 2005 to the $114^{\text {th }}$ Congress ending in 2016 that we have identified as mentioning climate change or related terms. We also include partial hearings of the $115^{\text {th }}$ Congress, relying on the transcripts available as of February 15, 2018. Publication can lag several months behind the actual hearing dates, so the hearings studied extend only into fall, 2017. The period from 2005 to 2017 included various combinations of party control of both Congressional houses and the Presidency, allowing for contrastive study of the effect of differing political alignments.

Using the Government Publishing Office repository of congressional hearings ${ }^{2}$ we searched all committees during the $109^{\text {th }}$ through the $115^{\text {th }}$ Congresses that might attend to climate change. We also included the hearing transcripts available for the $115^{\text {th }}$ Congress still in session at the time of this writing. These committees ranged from the obvious Senate Environment and Public Works Committee and House Energy and Commerce Committee to the less obvious Senate Foreign Relations Committee and House Small Business Committee. Within the list of hearings for each of these committees, we identified hearing titles indicating possible mention of climate change, and then searched for the terms climate change, global warming, carbon dioxide or greenhouse gas. Even a single mention of any one of these terms would lead to including the hearing transcript in the corpus, resulting in 1372 hearing transcripts collected for analysis. While anthropogenesis was occasionally mentioned, it was not a strongly identifying term; the search terms we used, however, did pick up the instances when anthropogenesis was a topic of concern. Therefore, we did not use it as a search term and in the following narratives we rely on the terms used in the transcripts. Though our procedures may have missed a few hearings, we are confident that we identified virtually all the major discussions of climate change and the overwhelming majority of minor or passing mentions. Figure 1 lists the number of hearings included in the corpus by Congress, House, and committee.

We downloaded each of these hearings and logged it on a spreadsheet by title, committee and subcommittee, major issue of the hearing, and centrality of climate change to the discussion indicated by frequency of mention or implied relation to the primary issue. Each hearing was further characterized as to how climate change

Transcripts of committee hearings, although published by the Government Publishing Office as is the Congressional Record are not officially part of the record, but only an adjunct, and they began being made available for purchase only in 1924 (Schmeckebier, 1925; Schmeckebier \& Eastin, 1969).

2 https://www.gpo.gov/fdsys/search/home.action 
Figure 1. Hearing Transcripts Included in Corpus for Analysis

Congress (Years)

House of REPRESENTATIVES (Total)

Agriculture

Appropriations

Armed Se
Budget

Education and Labor

Energy and Commerce

Foreign Affairs

Natural Resources

Oversight and Government Operation

Science (Science and Technology; Science, Space and Technolog)

Select Committee on Energy Independence and Global Warming

Small Business

Transportation and Infrastructure

Ways and Means

SENATE (total)

Agriculture, Nutrition, and Forestry

Appropriations

Banking, Housing, and Urban Affairs

Commerce, Science, and Transportation

Energy and Natural Resources

Environment and Public Works

Finance

oreign Relations

Health, Education, Labor, and Pensions

Indian Affairs

Small Business an Entrepreneurship

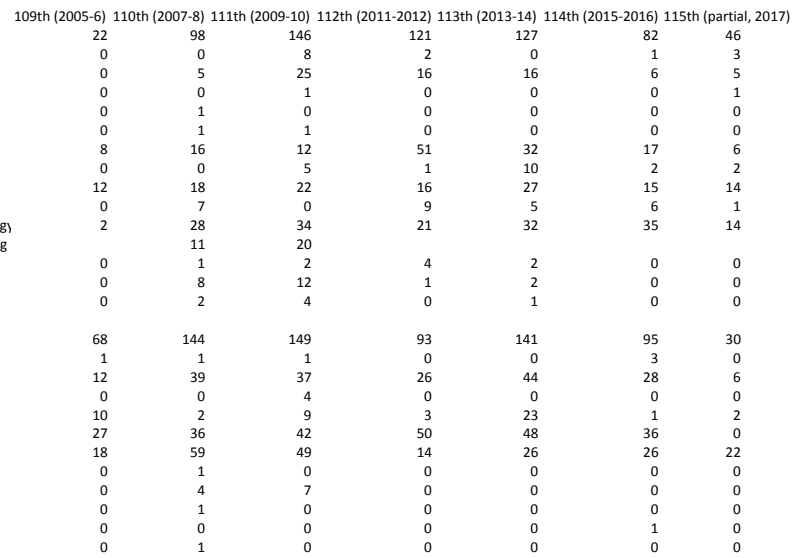

Total House Hearings mentioning Climate Change Issues examined=652 Total Senate Hearings mentioning Climate Change Issues examined $=720$

was presented by supporters and resistors of action. The analysis was carried out by determining the stasis of the hearing from the opening statements, and then examining each invocation of each of the key terms to see who was using it, whether in support or contestation, in what argumentative context, as part of establishing what position.

\subsection{Historical Analyses}

An historical analysis of hearings reveals how, within the relatively stable genres of hearings, committee chairs control stases in response to changing partisan control, political strategies, legislative priorities, and events within government, the country, and internationally. ${ }^{3}$ Within the defined issues of hearings we can see how individual members attempt to narrow or reorient the stases to advance their positions. The knowledge presented and recorded is determined by relevance to the questions that chairs ask and contested by members. The following summative narratives for each of the $109^{\text {th }}$ to $115^{\text {th }}$ Congresses characterize the political control, internal and external

3 Pace and issues for hearings are to some degree also shaped by the two-year electoral calendar, with a surge of new hearings during the first months of a new Congress asserting the themes or positions of the newly elected majority. Confirmation hearings also tend to be bunched at the beginning of the four-year Presidential term. After the summer break for the remainder of the first year, hearings tend to decrease, and are further reduced in the second year as possibilities of action become more limited and reelection takes more of the attention. Certain work, however, must be carried out throughout the term, such as budget hearings. 
events impacting hearings, and the framing of hearing stases that influence the published record of Congressional knowledge.

The narratives presented below for each Congress are complex because of the different positions not only of the political parties, but also the different committees in the two houses and even of individual members. Further as elections changed control of the houses of Congress and the Presidency and events outside of the US government changed the situation, responses in Congress also changed. We have necessarily left out much and focused on major differences, but still each of the stories is hard to encapsulate in a few sentences. To help readers follow the summative narratives, for each Congress we provide a table quantifying the number of relevant hearings in each committee, the number where climate change was a central or major issue or assumption, and whether there was any opposition. We characterize the levels of expressed opposition as follows: 1) Contesting the science or scientific processes; 2) accepting the science but opposing action on other grounds, such as the costs or inefficacy of regulation, the preference for technological and free market solutions, or the difficulty of gaining international cooperation leaving the US at a disadvantage; 3) not opposing climate change action but arguing for protection of coal or other fossil fuels; 4) no opposition or contestation. For the purposes of counting, cases where two or three of these kinds of arguments were made, the hearing was assigned only the most oppositional of the categories, so that, for example, hearings with contestations on the basis of science, government overregulation, and concern for the coal industry would be counted under contestation to science. Thus protection of the interests of coal and other fossil fuel industries was far more pervasive than the numbers might suggest.

\section{$4.51^{\text {th }}$ Congress $(2005-2006)$}

As Republican President George W. Bush began his second term, both houses of Congress were under Republican control with 230 votes to 203 Democratic votes, and the Senate 55 to $45 .{ }^{4}$ The previous Third IPCC report was four years old, and did not create new exigency for comment, and concerns about extreme weather events such as Hurricane Katrina were deflected by the difficulty of attributing any particular storm or series of storms to long-term climate change.

4 The party alignment numbers reported for this and following Congresses reflect the alignment reported in the Congressional Research Service, updated toward the end of each Congress, but numbers vary slightly over each Congress because of deaths and other departures, special elections, or party switches. These numbers also include independents with the party they caucus with, but not the nonvoting Delegates (American Samoa, District of Columbia, Guam, Northern Mariana Islands, Virgin Islands) and Resident Commissioner (Puerto Rico). 
Figure 2. Relevant Committee Hearings in 109th Congress

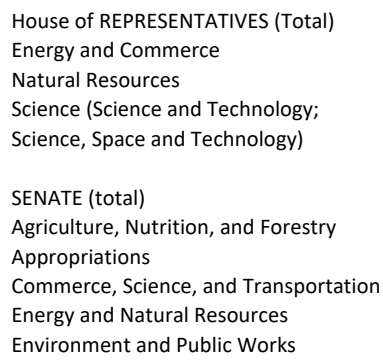

\begin{tabular}{|c|c|c|c|c|c|}
\hline $\begin{array}{l}\text { Relevant } \\
\text { Hearings }\end{array}$ & $\begin{array}{l}\text { Central or } \\
\text { Major }\end{array}$ & $\begin{array}{l}\text { science or } \\
\text { scientific } \\
\text { processes } \\
\text { contested }\end{array}$ & $\begin{array}{l}\text { not } \\
\text { contested, } \\
\text { but action } \\
\text { opposed on } \\
\text { other } \\
\text { grounds }\end{array}$ & $\begin{array}{l}\text { support for } \\
\text { coal } \\
\text { technologies }\end{array}$ & $\begin{array}{l}\text { no } \\
\text { oppositional } \\
\text { s mention or } \\
\text { contestation }\end{array}$ \\
\hline & 22 & 2 & 3 & 2 & 16 \\
\hline & 8 & 1 & 2 & 0 & 6 \\
\hline & 12 & 0 & 1 & 2 & 8 \\
\hline & 2 & 1 & 0 & 0 & 2 \\
\hline & 68 & 8 & 8 & 5 & 50 \\
\hline & 1 & 0 & 0 & 0 & 1 \\
\hline & 12 & 1 & 0 & 0 & 11 \\
\hline & 10 & 1 & 3 & 0 & 7 \\
\hline & 27 & 2 & 1 & 3 & 19 \\
\hline & 18 & 4 & 4 & 2 & 12 \\
\hline
\end{tabular}

Prior to this period, the Bush Administration had largely opposed action on climate change and expressed denial or equivocal positions. It had expunged much climate change information from official websites. Its 2002 Clear Skies Initiative did not address greenhouse gasses or climate change. On the other hand, some executive agencies carried out research and development activities with the aim of minimizing greenhouse gas emissions, although many Democrats saw these actions as too limited.

The Republican Congress also sent mixed messages on its stand on global warming, leading to some weak action. The proposed Clear Skies Act, which followed the administration Clear Skies Initiative and ignored greenhouse gasses, failed to pass in the $108^{\text {th }}$ Congress, and was reintroduced at the start of the $109^{\text {th }}$ in 2005. Hearings in the Senate Environment and Public Works Committee and a subcommittee, however, were framed around "multi-emissions legislation." This stasis allowed minority senators to raise the possibility of regulation of carbon dioxide and other greenhouse gasses, offer evidence on climate change, and question the witnesses on other pollutants about greenhouse gasses. Those opposing including greenhouse gasses in the bill generally did not contest the existence of climate change, instead arguing procedurally that this issue should be addressed in other legislation. The climate change issue led one Republican to vote with the eight Democratic votes to deadlock the committee, killing the proposal.

Instead, Congress rapidly passed with no Senate hearings and only one House subcommittee hearing The Energy Policy Act of $2005^{5}$ which reflected an "all of the

5 The legislation was referred to eight House committees for two days only, April 18-19, 2005, and the bill passed the House on April 21, 249-183 on a bipartisan vote. The Senate moved to consideration of 
above" approach to energy, matching incentives for technology to reduce greenhouse emissions with support for the coal industry and hydraulic fracturing. In this hearing, climate change was uncontested and greenhouse gas reduction was regularly cited as a benefit for various energy sources, including coal, though several witnesses and members of the committee criticized the law for not doing enough on climate change. Despite the limitations, this is the only act directed at climate change that passed Congress during the entire period studied, beyond regular agency budget bills.

The limited hearings and the protection of all energy interests in this act meant that Congress members did not need to expose their positions on climate change. Nonetheless, some committees in the Republican majority Congress soon began to take a more activist stand. The Senate Energy and Natural Resources Committee's two hearings on climate change showed unanimous bipartisan recognition that climate change was occurring, with much evidence setting a predicate for further action. In the first, the contested questions with appropriate evidence concerned the pace, degree of human contribution, and nature of solution. A second hearing's stasis was which action--market mechanisms, mandatory government controls, cap and trade, or other means--would be most effective and balance best with economic growth. Also the Senate Commerce Committee formed a special subcommittee on Global Climate Change and Impacts which held a hearing where members, bolstered by the testimony of scientific witnesses, expressed bipartisan agreement on climate change and its dire consequences, the Committee Chair Senator Stevens of Alaska and the Subcommittee Chair Senator Vitter of Louisiana, although both known as conservatives and friends of energy interests, were from states visibly impacted by climate change, as each explained.

The Senate Environment Committee chaired by the outspoken climate change denier Senator Inhofe of Oklahoma, however, framed the issues and established the record quite differently. A hearing on science in environmental policy making presented three witnesses denying climate change, but since the stasis was formed around the reality of climate change, two other witnesses, likely as courtesy concessions to the minority, reported that evidence for climate change was now incontrovertible, formed a scientific consensus, and warranted international action. This hearing left the record on reality of climate change divided and uncertain.

In another hearing Inhofe questioned whether the Kyoto Protocol, which the US had not signed, was faulted, which even climate change advocates had conceded. After evidence about Europe's inability to implement the protocol effectively, the question turned to whether the US administration was nonetheless acting adequately. This question made relevant the presentation of evidence about the pace of climate

the bill with no committee involvement at all June 11-23, passing on June 28 with an 85-12 bipartisan vote. The conference bill passed both houses in late July and was signed by the President on August 8, 2005. 
change and urgency of action, but also allowed consideration of economic costs of regulation and the benefits of technological and market-based solutions. The question of how to best advance US economic interests in the face of climate change also underlay a hearing on an energy partnership with Asian Pacific nations. One of the witnesses ${ }^{6}$ notably presented data that the cost of climate change will not fall as much on the richer countries, so it would not be in their interests to sacrifice to serve the interests of the poorer countries. A fourth hearing in the same committee under Inhofe's chairmanship questioned whether the media was stirring alarmism over climate change. In 12 hearings where climate change took a smaller role, however, it went uncontested.

Overall, in the Senate, beyond the hearings, which considered climate change in a high profile way, in the 59 hearings where climate change a minor or incidental role it was almost never contested. In 12 Appropriations Committee hearings, for example, climate change was accepted as part of the mission of the agencies examined, as it was in almost all appropriations hearings in both houses throughout the period studied.

In the House, there was a similar divide in the stance of the hearings in the different committees. The House Oversight Subcommittee of the Energy and Commerce Committee, led by Representative Whitfield of coal state Kentucky held a hearing on "Questions Surrounding the 'Hockey Stick' Temperature Studies.” The stasis narrowed further by questioning statistical procedures in the eight-year-old study, as criticized by the first two statistician witnesses. Although minority members and further witnesses pointed out more current studies supported the article's conclusion of rapidly increasing greenhouse effects, this hearing, in questioning methodological and publication procedures presented climate change science as questionable, lacking the clarity needed for action.

Two other house committees, however, considered climate change as an economic opportunity, with bipartisan acceptance of climate change. The Science Committee in considering climate change technology invited testimony about how industry can create profitable solutions and how government actions can affirmatively support that economic growth. A subcommittee of the Natural Resources Committee saw coal's economic future dependent on clean coal technology. In the other eighteen house hearings mentioning climate change in a minor or incidental role, the reality of climate change was never contested. As in the Senate, contestation tended

6 This witness was Danish political scientist Bjørn Lomborg, well known as a climate denier. He was called on at least five times to testify against climate action in committee and subcommittee hearings in the period studied. Other frequently appearing opposition witnesses were the University of Alabama earth scientist John Christy, testifying at least nine times, and the British journalist Lord Monckton, testifying at least three times. These three were also frequently cited in other hearings. 
to occur in focused settings led by a few individuals who wished to set down a record of uncertainty.

\section{6 $110^{\text {th }}$ Congress (2007-2008)}

Figure 3. Relevant Committee Hearings in 110th Congress

$\begin{array}{llllll}\text { Relevant } & \text { Central or science or } & \text { not } & \text { support } & \text { no } \\ \text { Hearings } & \text { Major } & \begin{array}{l}\text { scientific } \\ \text { processes } \\ \text { contested }\end{array} & \begin{array}{l}\text { contested, } \\ \text { but action } \\ \text { opposed } \\ \text { on other } \\ \text { grounds }\end{array} & \text { technologies } & \begin{array}{l}\text { mention or } \\ \text { contestation }\end{array} \\ & & & & \end{array}$

House of REPRESENTATIVES (Total)

Appropriations

Budget

Education and Labor

Energy and Commerce

Natural Resources

Oversight and Government Operations

Science (Science and Technology; Science,

Space and Technology)

Select Committee on Energy Independence

and Global Warming

Small Business

Transportation and Infrastructure

Ways and Means

SENATE (total)

Agriculture, Nutrition, and Forestry

Appropriations

Commerce, Science, and Transportation

Energy and Natural Resources

Environment and Public Works

Finance

Foreign Relations

Health, Education, Labor, and Pensions

Small Business and Entrepreneurship

98
5
1
1
16
18
7
28
11
1
8
2
144
1
39
2
36
59
1
4
1
1

15
1
0
0
3
2
4

67

4

0

1

1

15

3

24

9

1

8

1

97

1

38

2

25

28

0

1

1

1

The election switched control in both houses to Democrats who favored more vigorous action (with 235 votes to 200 Republican votes in the House and 51-49 in the Senate). Additionally, the fourth IPCC assessment released in the early days of the new Congress provided "unequivocal" evidence that climate change was occurring and was driven by human actions. The Bush administration, despite earlier ambiva- 
lence, endorsed the report, and Bush in his 2007 State of the Union address referred to the "serious challenge of global climate change." (Bush, 2007) The Supreme Court then ruled that the Environmental Protection Agency could regulate greenhouse gases under the Clean Air Act, even though the Bush administration did not intend to act on this authority (Greenhouse, 2007). With all these conditions favoring action, the Democratic majority proposed a cap and trade system to limit the greenhouse gasses each producer would be licensed to emit. These licenses could then be sold or traded. Legislation, however, faced a threatened Presidential veto, so Democrats turned to the strategy of establishing a compelling record to justify action in the future.

The proposed America's Climate Security Act of 2007 eventually obtained a 48-36 positive vote in the Senate, but failed to reach the filibuster threshold of 60 votes. The filibuster is a procedure in the Senate by which a minority can block debate or vote on a decision (Wawro \& Schickler, 2006). While formal floor consideration and vote occurred only in the Senate, the house held related hearings, to make climate change more visible in the record. The number of hearings mentioning climate change increased from the previous Congress in both houses from 22 to 98 in the House and 68 to 144 in the Senate. Hearings where climate change was the central or a major issue increased at an even greater proportion, from 2 to 47 in the house and from 8 to 67 in the Senate. In all committees but one climate change's reality was not seriously contested, though protecting energy interests, was sometimes expressed.

In the Senate even committees apparently peripheral to the issue held hearings on implications for small business or public health. More expectedly, the Senate Energy and Natural Resources committee had 36 hearings related to climate change with 25 centering on climate change issues. In all there was uniform bipartisan acceptance, sometimes explicitly stated, with only a few expressions about protecting coal, clean coal technologies, or specific oil leases. The hearings made relevant extensive data on the reality and impacts of climate change, current initiatives and actions, and other potential solutions. The Appropriations Committee had 39 hearings relevant to climate change with no contestation.

The Senate Environment and Public Works Committee, now under the chairmanship of Senator Boxer with Senator Inhofe the ranking minority member, however, became the center of contestation. With 59 hearings mentioning climate change issues, 24 centered on climate change, with 4 more as a major concern. 24 of these 28 were contested. 24 of the remaining 31 hearings where climate change took a lesser role showed no opposition or contestation. The most complete debate occurred when the stasis addressed direct actions, such the proposed Climate Security Act, policies to decrease greenhouse gasses, and implications for implementation of the Supreme Court decision.

On the first day of the new Congress, in an unusual hearing of this committee, all Senators were invited to present their views and supporting arguments. Of the thirty-four senators who put their views and evidence on the record, 28 affirmed climate change and supported immediate action without reservations. This included 
five Republicans, including one member of the committee. Four other Republican members of the committee also affirmed climate change was occurring, but had reservations about the approach to be taken and concern for the impacts of action on the economy. From the committee, only Senator Inhofe actually questioned the reality of climate change and the science behind it, along with one other Republican not on the committee. Three Republicans on the committee who did not testify elsewhere committed to recognition and action on Climate Change.

Inhofe's denial of climate change continued in hearings throughout the term. Four other Republicans at times questioned policy choices, approaches, or economic consequences of particular proposals, but did not contest the reality. The four remaining Republicans on the committee almost never opposed and sometimes supported action. For example, in a hearing devoted to former Vice-President's Gore's testimony on the science and costs of climate change, Senator Inhofe was the sole voice citing scientists to the contrary and asking skeptical questions. Two other Republican Senators spoke in support of Gore's testimony.

The House also had more hearings with little or no contention except for a single committee. Of the 98 hearings in the House, in 67 showed no resistance to the climate change or action. In the 32 instances of resistance or support for fossil fuels 15 involved questioning the certainty or meaning of scientific findings or processes, and that sometimes only in passing.

Even the Select Committee on Energy Independence and Global Warming, especially created this term by the Democratic leadership, evoked remarkably little contention, even though 9 of 11 hearings considered climate change as the central challenge, in considering geographic and economic impacts, current initiatives, and policy alternatives. The only opposition to action was by Representative Sensenbrenner, who at one point questioned anthropogenic causation and elsewhere opposed regulation and argued for free market solutions following what he called the four principles of a Republican solution: tangible environmental benefits to Americans; advancing technology; protecting US jobs; and requiring global participation.

The Science and Technology Committee held 28 related hearings of which 10 had Climate Change as central, including one presenting the findings of the recently released fourth IPCC report. This hearing over three days, presented fifteen scientists, all who took part in the IPCC reports, allowing full and direct presentation of the current case for climate change. The findings were not contested, but some representatives argued for technology and free market approaches instead of regulation. In the other hearings of the committee climate change was contested only four other times, in passing, from the disempowered sidelines.

In the eighteen relevant hearings in House Natural Resources committee the story was much the same, with no contestation on such issues as water policy, wildlife, and carbon sequestration. In a shift of venue and stases from the hearings in the Environment Committee in the previous Congress, hearings on distortion of governmental and scientific processes were now carried out in in the House Oversight Committee 
and the Science and Technology Committee and focused on suppression of climate science rather than climate change activist biases in science or the media.

The Energy and Commerce Committee was the one House location of major contestation to climate change action in its sixteen hearings mentioning the issue. Ranking Minority Member Joe Barton was the most vocal, but still somewhat muted. Stases on technological and economic opportunity, such as carbon sequestration or alternative fuels evoked no opposition but only evidence of economic potentials, as long as they were not encumbered by what was perceived as burdensome regulation. Other hearings about policy choices such as involving fuel standards, state and local concerns, or international cooperation made some opposition relevant. In two cases questions over the pace of climate change suggested there was no need to rush plans, and in two others there was some questioning over whether dissenting science was ignored. Overall, fifteen of the sixteen showed opposition to proposed actions or concern to protect fossil fuels.

Only three hearings in the Subcommittee on Energy and Air Quality showed direct contestation of climate change. A hearing directly posing the question "Climate Change: Are Greenhouse Gas Emissions from Human Activities Contributing to the Warming of the Planet?" invited negative response and evidence. In a hearing on automobile emissions standards, while all witnesses from auto manufacturers and unions presented themselves as proactive on addressing climate change and emissions, Barton asked skeptical questions about nonanthropogenic greenhouse gases outweighing anthropogenic. Finally, a joint hearing between this subcommittee and a subcommittee of the Science Committee pitched the testimony of Al Gore against that of longstanding climate skeptic Bjørn Lomborg. Gore first laid out the full case for action. Lomborg accepted that climate change is real, but argued that impacts are exaggerated, and that solutions need to ensure that costs do not outweigh benefits or obscure other problems.

So with the switch of control of both houses, the stases move towards acceptance or assertion of climate change. Building the case for major legislation expanded the opportunity for presentations of the positive evidence and created opportunities for opposition. However, the fourth IPCC report and the Bush administration acceptance of climate change made it more difficult for the opposition to argue denial or the science was unsettled. Further, the door was opened to exploring the relevance of climate change to a wide range of issues from health to polar bears to small businesses. 


\subsection{The $111^{\text {th }}$ Congress $(2009-2010)$}

Figure 4. Relevant Committee Hearings in 111th Congress

\begin{tabular}{|c|c|c|c|c|c|}
\hline $\begin{array}{l}\text { Relevant } \\
\text { Hearings }\end{array}$ & $\begin{array}{l}\text { Central or } \\
\text { Major }\end{array}$ & $\begin{array}{l}\text { science or } \\
\text { scientific } \\
\text { processes } \\
\text { contested }\end{array}$ & $\begin{array}{l}\text { not } \\
\text { contested, } \\
\text { but action } \\
\text { opposed on } \\
\text { other } \\
\text { grounds }\end{array}$ & $\begin{array}{l}\text { support for } \\
\text { coal } \\
\text { technologies }\end{array}$ & $\begin{array}{l}\text { no } \\
\text { oppositional } \\
\text { mention or } \\
\text { contestation }\end{array}$ \\
\hline
\end{tabular}

House of REPRESENTATIVES (Total)

Agriculture

Appropriations

Armed Services

Education and Labor

Energy and Commerce

Foreign Affairs

Natural Resources

Science (Science and Technology;

Science, Space and Technology)

Select Committee on Energy

Independence and Global Warming

Small Business

Transportation and Infrastructure

Ways and Means

\section{SENATE (total)}

Agriculture, Nutrition, and Forestry

Appropriations

Banking. Housing. and Urban Affairs

Commerce, Science, and

Transportation

Energy and Natural Resources

Environment and Public Works

Foreign Relations

$\begin{array}{rr}146 & 69 \\ 8 & \\ 25 & \\ 1 & \\ 1 & \\ 12 & 11 \\ 5 & \\ 22 & \\ & \\ 34 & \\ & \\ 20 & \\ 2 & \\ 12 & \\ 4 & \\ & \\ 149 & 48 \\ 1 & \\ 37 & \\ 4 & \\ & \\ 9 & \\ 42 & 16 \\ 49 & 16 \\ 7 & \end{array}$

\begin{tabular}{rrrr}
\multicolumn{2}{c}{ grounds } & & \\
$\mathbf{3 0}$ & $\mathbf{3 1}$ & $\mathbf{2}$ & $\mathbf{8 3}$ \\
2 & 2 & 0 & 4 \\
1 & 3 & 0 & 21 \\
0 & 0 & 0 & 1 \\
0 & 1 & 0 & 0 \\
3 & 8 & 1 & 0 \\
3 & 0 & 0 & 2 \\
4 & 5 & 0 & 13 \\
& & & \\
11 & 0 & 0 & 23 \\
& & & \\
3 & 11 & 1 & 5 \\
0 & 0 & 0 & 2 \\
0 & 0 & 0 & 12 \\
3 & 1 & 0 & 0 \\
& & & \\
$\mathbf{8}$ & $\mathbf{2 6}$ & $\mathbf{3}$ & $\mathbf{1 1 2}$ \\
0 & 0 & 0 & 1 \\
0 & 0 & 0 & 37 \\
0 & 0 & 0 & 4 \\
0 & & & \\
1 & 0 & 1 & 35 \\
7 & 5 & 1 & 22 \\
0 & 19 & 1 & 5
\end{tabular}

The election of the Democratic President Barack Obama brought even greater Democratic dominance with 255 votes to 180 Republicans in the House and 59 to 41 in the Senate. The financial crisis of 2008 and health care dominated the legislative agenda. Nonetheless, work continued on cap and trade legislation. As various agencies and programs took a more active concern for climate change, more committees considered it relevant to more hearings, for a total of 149 in the Senate and 146 in the House. Some anticipatory hearings considered how US might position itself in the Copenhagen climate conference in December 2009, but absence of a meaningful agreement was followed by no congressional hearings.

In the Senate the newly perceived extended relevance of climate change is exemplified by the seven hearings in the Foreign Relations Committee directed towards US leadership at the Copenhagen conference, cooperation with China, and the role of climate change in national security and global economic recovery. More typically, the Senate Appropriations Committee had 37 hearings with no contestation. The 
Energy and Natural Resources Committee's forty-two related hearings contained only sporadic resistance to the climate change agenda. In the fourteen hearings centrally devoted to climate change issues, only one had any questioning of the science, and only three others raised economic costs or problems with regulatory solutions. Based on hearings in the previous congress in July 2009 the committee passed the America's Climate Leadership Act of 2009 by a 15-8 bipartisan vote. Without 60 votes to overcome the filibuster threshold, however, the full Senate did not vote on it. Other hearings considered house-passed legislation, policies related to water, forest, and energy, funding agencies, and approving nominations, all under the uncontested assumption of the need for action climate change, despite some concerns for the interests of various energy sectors, including coal.

The Environment and Public Works Committee with ranking minority member Inhofe, however, remained the locus of resistance in the $111^{\text {th }}$ Senate. While Inhofe continued to question the science, four other minority members accused the EPA of biased science, claimed regulations were ineffective and harmful, complained about using the Endangered Species Act to carry out climate policy, and argued the priority of economic growth over climate issues. Two other minority members of the committee, however, did not object to action. In all twelve hearings where climate change was the central issue, and four where it was a major concern showed some contestation. In November 2009, nonetheless, the Committee passed a version of the house bill, renamed the Clean Energy Jobs and American Power Act of 2009, by a vote of 11-1 with all Republicans boycotting. This bill also failed to overcome the filibuster threshold for a full Senate vote. In all 22 hearings where climate change only took a minor or incidental role, there was no contestation.

In the House, while anticipation of Copenhagen and major legislation also created potential sites of contestation, chairs strategically controlled stases to limit opposition. The Select Committee on Energy Independence and Global Warming continued as a key site for considering climate change with all 20 of its hearings mentioning it and 18 centrally focusing on it or relying on it as a central assumption. All members of the committee regularly reiterated bipartisan agreement on climate change, with contestation limited to policy differences. In four hearings preparing for Copenhagen, all members shared concern for establishing the US position, including the protection of US intellectual property. In other hearings, all members agreed that fraudulent letters sent to Congress before a vote and black carbon soot were bad and smart grids, resilience and adaptation, clean coal technologies, and jobs were good. But hearings about government programs and regulation allowed questioning of whether government actions were effective, wasteful or harmful. In three hearings on the science itself, however, the minority questioned the IPCC data set, said the science was unsettled, and repeating details of the six-year old Climategate email scandal where some British scientists were accused of manipulating data. In fact, in one hearing Republicans attempted to shift the stasis from examination of the administration position to Climategate. 
The Energy and Commerce Committee had 11 hearings where climate change was the central issue, all dealing with energy policy issues, most of them related to the American Clean Energy Security Act of 2009. Each one of these hearings evoked contestation, but carefully framed issues limited the contestation. The initial hearing of the series was devoted to the Climate Action Partnership of industry and NGO leaders testifying how their organizations were working to prevent climate change; no representative picked a fight against such a strong alliance of industrial leaders. The next hearing on the climate crisis, however, did invite contestation whether a crisis existed, and the minority witness presented findings that suggested the science wasn't settled. Since hearings on coal, consumer protection, or offsets, all sought economic efficiency, contestation and supporting evidence concerned only details impacting specific groups. In a lengthy hearing devoted to marking up the drafted bill, discussion focused on particulars of the legislation, with no attention to the science.

In the Science and Technology Committee, with 34 hearings mentioning climate change, 6 where it was central and 5 others a major concern, some minority members contested climate change action, led by the climate change skeptic Representative Rohrabacher. Hearings on water policy, research, clean coal, or other technological fixes evoked no contestation. But others evoked confrontation on the basic science, most notably in a hearing on monitoring emissions, which created an opportunity to discuss whether there was a scientific consensus on climate change. In another hearing "A Rational Discussion of Climate Change" nine majority witnesses presenting a full scientific case were countered by three minority witnesses, claiming that climate change was slower and less pressing than predicted, that scientific consensus was lacking, and that the Climategate email scandal discredited advocates. The email scandal comes up in other hearings, as do other claims of politicization of science. Overall 11 hearings include some claim about the insufficiency, lack of consensus, or bias of the science. Even the Ways and Means committee, which rarely held hearings related to climate change, had four where climate change was central, three of which had some skepticism about science.

The House Oversight and Government Reform Committee, on the other hand, held no hearings related to climate change. The Democratic committee chair did not wish to raise questions about the scientific process, government support of it, or media presentations. Two hearings in the Small Business Committee seeing opportunities in new energy sources, and 12 in the Transportation Committee examining impacts of climate change for planning also evoked no contestation. The House Appropriations Committee, in its 25 relevant hearings, showed little substantive challenge to climate change or action, though four had passing comments on unsettled science or misplaced priorities.

In both houses, the stases were uniformly directed towards expanding the relevance of climate change to a wider range of issues, taking action, and passing major legislation, though the latter ultimately failed. The hearings developed a broad record 
of evidence. In the Senate this record was only contested in one committee, while in the House, the minority in a number of committees sought within hearing stases to question both science and policies. The committee chairs, however, used control of stases to narrow contestation.

\section{$4.8112^{\text {th }}$ Congress $(2011-2012)$}

Figure 5. Relevant Committee Hearings in 112th Congress

\begin{tabular}{|c|c|c|c|c|c|}
\hline $\begin{array}{l}\text { Relevant } \\
\text { Hearings }\end{array}$ & $\begin{array}{l}\text { Central or } \\
\text { Major }\end{array}$ & $\begin{array}{l}\text { science or } \\
\text { scientific } \\
\text { processes } \\
\text { contested }\end{array}$ & $\begin{array}{l}\text { not } \\
\text { contested, } \\
\text { but action } \\
\text { opposed on } \\
\text { other } \\
\text { grounds }\end{array}$ & $\begin{array}{l}\text { support for } \\
\text { coal } \\
\text { technologies }\end{array}$ & $\begin{array}{l}\text { no } \\
\text { oppositional } \\
\text { mention or } \\
\text { contestation }\end{array}$ \\
\hline
\end{tabular}

House of REPRESENTATIVES (Total)
Agriculture
Appropriations
Energy and Commerce
Foreign Affairs
Natural Resources
Oversight and Government Operation
Science (Science and Technology;
Science, Space and Technology)
Small Business
Transportation and Infrastructure
SENATE (total)
Appropriations
Commerce, Science, and
Transportation
Energy and Natural Resources
Environment and Public Works

House of REPRESENTATIVES (Total)

Agriculture

ppropriations

Oversight and Government Operations

Small Business

Transportation and Infrastructure

Environment and Public Works

$\begin{array}{rrrrrr}\mathbf{1 2 1} & \mathbf{1 8} & \mathbf{7} & \mathbf{5 8} & \mathbf{7} & \mathbf{4 9} \\ 2 & 1 & 0 & 1 & 0 & 1 \\ 16 & 0 & 0 & 5 & 2 & 9 \\ 51 & 13 & 2 & 28 & 2 & 19 \\ 1 & 0 & 0 & 0 & 0 & 1 \\ 16 & 0 & 2 & 4 & 0 & 10 \\ 9 & 2 & 0 & 6 & 2 & 1 \\ & & & & & \\ 21 & 2 & 3 & 10 & 1 & 7 \\ 4 & 0 & 0 & 4 & 0 & 0 \\ 1 & 0 & 0 & 0 & 0 & 1 \\ & & & & & \\ 93 & 14 & 2 & 10 & \mathbf{1} & \mathbf{8 0} \\ 26 & 5 & 0 & 0 & 0 & 26 \\ & & & & & \\ 3 & 1 & 0 & 0 & 0 & 3 \\ 50 & 7 & 1 & 6 & 1 & 42 \\ 14 & 1 & 1 & 4 & 0 & 9\end{array}$

The election gave Republicans control of the House with 241 votes to 192 voting Democrats. The Senate, however, maintained a Democratic majority of 53 votes to 47 Republicans. Though the Democratic President Obama continued in office, the Republican House eliminated the possibility of major climate change legislation, thereby decreasing exigency to connect climate change to a range of other issues and initiatives. Yet, climate change remained an accepted assumption when most matters of ordinary business arose.

Even though the Senate remained Democratic, hearings examining direct action vanished, and the total number of hearings mentioning climate change decreased to 93 from the previous 149. Even more dramatically, it was the central issue in only 6 hearings, down from 37. While the Environment and Public Works Committee remained a site of substantial resistance, the Chair scheduled no hearings where 
climate change was the central issue, and there was only one mandatory nomination hearing where it was even a major concern. Ranking Member Inhofe was limited to trying to limit the mandate of the Director of the US Fish and Wildlife Service and the Assistant Secretary of Interior for Fish, Wildlife and Parks on procedural grounds. In an EPA budget hearing Inhofe contested whether CO2 should be considered a pollutant under that agency. In a hearing on the Clean Air Act and Jobs, two witnesses in passing raised uncertainties about the degree and pace of climate change. In the eleven other hearings, where climate change was mentioned in passing, only once did Inhofe mention the wasted expenses of regulation. The other minority members did not even raise objections throughout the term.

The Energy and Natural Resources Committee did have five hearings where climate change took a central role, down from thirteen in the previous Congress. These addressed only mitigating impacts (such as on water resources) or protecting interests of coal through clean energy technology, rather than combatting climate change directly. In all these there was no contestation of climate change. In the fortyfive other hearings where climate change had a lesser role, only six had minor skeptical asides. In the 26 hearings in the Senate Appropriations committee on the budgets of various agencies, climate change was unquestioned as part of the agencies' work.

The Republican-controlled House, however, created hearing stases calling into question overregulation, mismanagement, and scandal involving climate change initiatives. Yet the facts of climate change or human causation were little questioned. The elimination of the Select Committee on Energy Independence and Global Warming both removed a venue to advance climate change regulation and delinked climate change from energy independence.

The renamed Science, Space and Technology Committee had previously established evidence for climate change, but now focused on removing regulation or advancing economically advantageous technologies in its 21 hearings mentioning climate change. The two hearings where climate took a central role called into question biases in administration science and policy processes, including inappropriate shifting of agency missions. Twelve other hearings overseeing administrative agencies and budgets raised similar questions.

The Small Business Committee's four hearings mentioning climate change took stases from the costs of environmental regulation for small business, such as "Are Excessive Energy Regulations and Policies Limiting Energy Independence, Killing Jobs and Increasing Prices for Consumers?” The Oversight and Government Reform Committee's nine hearings similarly examined the job and economic costs of regulation, with such titles as “How Obama's Green Energy Agenda is Killing Jobs.” In these hearings the relevant facts concerned ineffective government actions, costs to businesses and the economies, and anecdotes that highlighted regulatory overreach. The Democratic members could only object from the sidelines that regulations were needed and were being carried out fairly and moderately. 
The House Energy and Commerce Committee, as in the past, was a major locus of contention with 51 hearings, with seven centrally focused on climate change and six others treating it as a major concern, but stases switched to jobs and the economic consequences of regulation, with a related switch of the relevant facts presented. Many of these hearings were part of a series of 29 hearings on the American Energy Initiative in the Subcommittee on Energy and Power, setting out an economic agenda, including critiques of regulation. In other hearings where climate change was mentioned in lesser roles, the same objections were made concerning burdens and costs of regulation, including scandals and mismanagement. Only one hearing centrally raised the science of climate change with four scientific witnesses presenting evidence of climate change matched with four others that questions doubts about the scientific consensus.

The House Natural Resources Committee, however, was much quieter with less contention, and fewer hearings that mentioned climate change with none where it took a central or major role. Nine had no contestation, four others had passing mention of overregulation or agency bias, and one had a passing accusation that climate change was a hoax with proposed actions a waste of money. The sixteenth climate change related hearings in the Appropriations Committee, while raising questions about the efficiency of the agencies, did not raise any doubts about climate change or the necessity of related programs.

With split leadership between the houses, the Senate did not push a positive agenda in its hearings, just carrying forward existing programs, while the House used hearings to establish the case for a deregulatory, energy growth agenda. Between the two little was added to the record to advance action on climate change, but much was added to the oppositional record, even though the facts of climate change were only sporadically contested.

\section{$4.9113^{\text {th }}$ Congress (2013-2014)}

Congress remained divided. The House had 234 Republican votes to 201 Democratic; the Senate had 55 Democratic votes to 45 Republican. The Democratic President Obama, reelected for a second term, announced in June 2013 his Climate Action Plan, to be carried out by executive actions. The Fifth IPCC Assessment Report was finalized in 2014 with parts released over that year. Both these elicited active, but different responses from the two houses of Congress.

In the Senate, as in the previous Congress, with no climate change legislation being pursued, climate change was central to few hearings, and little contestation appeared, except for one committee. The Energy and Natural Resources Committee held 48 hearings mentioning climate change, but only one regionally focused hearing on sustainability goals in the Pacific centrally focused on it. It was a major concern in only seven others, on such issues as drought, water infrastructure, and the nomi- 
Figure 6. Relevant Committee Hearings in 113th Congress

\begin{tabular}{|c|c|c|c|c|c|c|}
\hline & $\begin{array}{l}\text { Relevant } \\
\text { Hearings }\end{array}$ & $\begin{array}{l}\text { Central or } \\
\text { Major }\end{array}$ & $\begin{array}{l}\text { science or } \\
\text { scientific } \\
\text { processes } \\
\text { contested }\end{array}$ & $\begin{array}{l}\text { not } \\
\text { contested, } \\
\text { but action } \\
\text { opposed on } \\
\text { other } \\
\text { grounds }\end{array}$ & $\begin{array}{l}\text { support for } \\
\text { coal } \\
\text { technologies }\end{array}$ & $\begin{array}{l}\text { no } \\
\text { oppositional } \\
\text { mention or } \\
\text { contestation }\end{array}$ \\
\hline House of REPRESENTATIVES (Total) & 127 & 24 & 6 & 44 & 8 & 69 \\
\hline Appropriations & 16 & 0 & 0 & 0 & 0 & 16 \\
\hline Energy and Commerce & 32 & 11 & 0 & 19 & 4 & 9 \\
\hline Foreign Affairs & 10 & 0 & 1 & 0 & 0 & 9 \\
\hline Natural Resources & 27 & 2 & 1 & 6 & 0 & 20 \\
\hline Oversight and Government Operations & 5 & 0 & 1 & 4 & 0 & 0 \\
\hline $\begin{array}{l}\text { Science (Science and Technology; } \\
\text { Science, Space and Technology) }\end{array}$ & 32 & 11 & 3 & 15 & 3 & 11 \\
\hline Small Business & 2 & 0 & 0 & 0 & 1 & 1 \\
\hline Transportation and Infrastructure & 2 & 0 & 0 & 0 & 0 & 2 \\
\hline Ways and Means & 1 & 0 & 0 & 0 & 0 & 1 \\
\hline SENATE (total) & 141 & 23 & 4 & 19 & 1 & 117 \\
\hline Appropriations & 44 & 4 & 0 & 0 & 1 & 43 \\
\hline Commerce, Science, and Transportation & 23 & 2 & 0 & 0 & 0 & 23 \\
\hline Energy and Natural Resources & 48 & 8 & 0 & 10 & 0 & 38 \\
\hline Environment and Public Works & 26 & 9 & 4 & 9 & 0 & 13 \\
\hline
\end{tabular}

nation of the Secretary of Energy. In these, only a few questions were raised about regulations and their costs, impact on coal, or limiting the scope of action of various agencies. The Commerce Committee as in the past showed bipartisan recognition of climate change and support. Of 23 hearings mentioning climate change, it was central only in one on coastline adaptation in Florida, driven by local challenges rather than the larger problem. The Appropriations Committee had 44 hearings with no contestation of climate change.

The Environment and Public Works Committee, however, had seven hearings where climate change was central. These centrally focused hearings mostly addressed the President's Climate Action Plan and the new IPCC report. With titles such "Climate Change: It's Happening Now" the stases made relevant a full review of the evidence for action. With Inhofe continuing as the Ranking Minority Member, 6 of the 7 had some contestation (including 4 contesting the science). Of the total of 26 hearings mentioning climate change, 13 had some form of contestation. Senators Inhofe, Barroso, and Vitter offered some flat denials of the scientific consensus, of a link between climate change and extreme weather events, and of human causation. In other cases, the minority scientific witnesses argued that the costs were not as great as other scientists were projecting, and that adaptation was preferable to aggressive regulation. Elsewhere the concern was the economy, jobs, or the ineffectiveness and harms of regulation.

In the Republican-controlled House, three committees--Energy and Commerce; Science, Space, and Technology; and Oversight and Government Reform--actively framed hearings in opposition to climate change. In the other committees, such as 
Appropriations (with 16 hearings mentioning the issue), Foreign Affairs (10), and Natural Resources (27), climate change took a back seat and evoked little opposition beyond a few comments on the futility or harms of regulation. In Foreign Affairs, climate change in fact was frequently recognized as a threat to international peace in relation to such issues as water shortage conflicts.

In two of the three committees that contested climate change action in a focused way, the stases were framed on value (coal and the economy) and procedure (the dangers or ineffectiveness of regulation), and not on the evidence of climate change and its impacts. Of the Energy and Commerce Committee's 32 hearings mentioning climate change, 25 raised difficulties with administration actions such as in the hearings on "The EPA's Regulatory Threat to Affordable, Reliable Energy: The Perspective of Coal Communities." The supporters of actions argued for the necessity and value of actions, but they were granted few witnesses beyond the administration officials being-cross examined. Where issues were framed around economic development, however, mention of climate change was let pass without comment. Similarly, the House Oversight and Government Reform committee continued the attack on Obama administration actions in five hearings.

The Science, Space, and Technology Committee, however, continued to question the science. The hearing "Examining the U.N. Intergovernmental Panel on Climate Change Process" presented four witnesses with smaller roles in the IPCC process who reported marginalization of dissident views. The hearing record questioned the authority of the IPCC findings that served to justify Obama administration actions. Of the 32 hearings in this committee involving climate change (including eight as a central issue, with 3 more as a major concern), 21 contested climate change and administrative actions. A recurrent issue was bias in administration science, such as diverting funding from weather monitoring to climate sensing. Most of the 11 noncontested mentions were incidental; only in one budget hearing was climate change a major concern with no contestation.

\subsection{The $114^{\text {th }}$ Congress (2015-2016)}

During the last two years of the Obama presidency, both houses of Congress came under Republican control, in the House 247 to 187 and the Senate 54 to 46. During this period the Obama administration participated in the Paris Climate Agreement committing nations to self-determined goals for decreasing greenhouse gas emissions. In anticipation of the Paris Conference Pope Francis released an encyclical Laudato Si. On December 12, 2015, the agreement was passed by consensus among the negotiating nations, and later signed by 196 nations. Obama committed the US by executive action rather than Congressionally approved treaty. Committee hearings in both houses contested the economic and procedural premises of the agreement, but with little questioning of climate change's existence or the role of human causation. Other 
Figure 7. Relevant Committee Hearings in 114th Congress

\begin{tabular}{|c|c|c|c|c|c|c|}
\hline & $\begin{array}{l}\text { Relevant } \\
\text { Hearings }\end{array}$ & $\begin{array}{l}\text { Central or } \\
\text { Major }\end{array}$ & $\begin{array}{l}\text { science or } \\
\text { scientific } \\
\text { processes } \\
\text { contested }\end{array}$ & $\begin{array}{l}\text { not } \\
\text { contested, } \\
\text { but action } \\
\text { opposed on } \\
\text { other } \\
\text { grounds }\end{array}$ & $\begin{array}{l}\text { support for } \\
\text { coal } \\
\text { technologies }\end{array}$ & $\begin{array}{l}\text { no } \\
\text { oppositional } \\
\text { mention or } \\
\text { contestation }\end{array}$ \\
\hline House of REPRESENTATIVES (Total) & 82 & 18 & & 50 & 3 & 25 \\
\hline Agriculture & 1 & 0 & & 1 & 0 & 0 \\
\hline Appropriations & 6 & 1 & & 2 & 2 & 2 \\
\hline Energy and Commerce & 17 & 7 & & 16 & 0 & 1 \\
\hline Foreign Affairs & 2 & 0 & & 0 & 0 & 2 \\
\hline Natural Resources & 15 & 4 & & 5 & 0 & 6 \\
\hline Oversight and Government Operations & 6 & 0 & & 4 & 0 & 2 \\
\hline Science, Space and Technology & 35 & 6 & & 22 & 1 & 12 \\
\hline SENATE (total) & 95 & 12 & & 20 & 0 & 73 \\
\hline Agriculture, Nutrition, and Forestry & 3 & 0 & & 0 & 0 & 3 \\
\hline Appropriations & 28 & 0 & & 3 & 0 & 25 \\
\hline Commerce, Science, and Transportation & 1 & 0 & & 0 & 0 & 1 \\
\hline Energy and Natural Resources & 36 & 0 & & 3 & 0 & 33 \\
\hline Environment and Public Works & 26 & 12 & & 14 & 0 & 10 \\
\hline Indian Affairs & 1 & 0 & & 0 & 0 & 1 \\
\hline
\end{tabular}

than those hearings, the general strategy was not to hold hearings where climate change would take a central role, with only 12 with 6 more as a major concern in the House (out of 82 total) and 9, with 3 more a major concern in the Senate (out of 95).

The Senate Energy and Natural Resources Committee had 36 hearings mentioning climate change, but mostly because of incidental interjections by Democratic senators in discussions of other issues such as forest health, energy efficiency or Arctic economic opportunities In a few cases witnesses mentioned climate change or greenhouse gases in passing. Such comments were regularly ignored by the majority, with only three minor demurrals. The same strategy of ignoring incidental mention appears in the three hearings in the Agriculture, Nutrition, and Forestry Committee and one in the Commerce, Science, and Transportation Committee. These committees have no stases framing climate change as a central or major issue, or paying attention to the Obama Clean Energy Plan, Pope Francis, or the Paris Agreement. Even in the 28 hearings of the Appropriations Committee, agency reports or witnesses mentions of climate change are regularly ignored, except for three occasions questioning specific rules.

The Environment and Public Works Committee, with Senator Inhofe returning as the committee chair, however, directly contested action in 13 of the 26 hearings mentioning climate change, but they generally accepted the reality of climate change, and the contestation moved to other stases. Seven hearings made climate change central, with two directly on Paris, ahead of the meetings. The first focused on overregulation and government overreach, though the stasis did provide an opportunity for the proponents to make the affirmative case for climate change action. Even the chair in 
selecting witnesses had to give respect to the strength of the evidentiary argument, with three of the five witnesses testifying on the pressing need for action. The final two witnesses, however, made legal arguments that the president did not have the power to act independently of Congress in entering into international agreements. In another hearing just before the Paris meeting, economic concerns were raised along with the procedural.

Four hearings on aspects of Obama's Climate Action Plan and other EPA policies, answered every argument for action with a counterargument. For example, one former military officer's testimony presenting the national and global security threat from climate change is matched with another retired officer testifying climate change is not a cause of war. Finally, one hearing centrally questioned whether greenhouse gasses should be regulated at the national or state level. Federalism in regulation also came up in hearings where climate change took a more minor role.

Confirming the general tacit acceptance of climate change in all the Senate hearings (but also the majority's concern for the economic interests of the energy industry) was the 98 to 1 approval of an amendment to an act approving a controversial pipeline that "climate change is real and not a hoax." Even Inhofe and Sessions (then senator from Alabama also with a long record of climate change denial) voted for this amendment. But a follow-up amendment attributing the change to human action received only a 50-49 majority, falling short of the 60 votes needed to avoid filibuster. Similarly, a resolution later that year introduced by Democrat Franken in support of the papal encyclical "Laudato Si" gained a 50-38 majority, with some bipartisan support, but again fell short of the filibuster mark.

The House took a more confrontational strategy, even though the science of climate change again was little contested. Three committees held hearings actively opposing Obama administration regulation. The Energy and Commerce Committee held 17 hearings that mentioned the issue, with two focusing centrally and five more with a major role. Six of these seven the stases questioned the economic consequences and ineffectiveness of the EPA's actions. The seventh, on the EPA budget, accepted climate change within the agency mandate, with no contestation; the Democratic minority, however, used this ordinary business to assert the need for action and the value of the EPA programs. Of the remaining 10 hearings where climate change took a lesser role, all but one evoked opposition to regulatory action.

In the 15 hearings in the Natural Resources Committee mentioning climate change, four had climate change as the central issue with all focused on regulation or the policies and science behind the regulations. While three of them had arguments over the scientific bases of actions, there was no contestation of climate change itself, but only that the phenomenon was more complex than the administration was presenting it. Several other hearings framed around related areas of regulation such as endangered species, oceans and water policy, transportation or energy, included evidence of overregulation, costs, and ineffectiveness of regulation. The six instances where climate change was not contested were all minor or incidental. 
The most vigorous questioning of climate change action occurred in the Science, Space, and Technology Committee, with 35 hearings on the topic. The seven hearings where climate change took a central role focused on administration actions, with typical titles as "Impact of EPA'S Clean Power Plan on States" and "Paris Climate Promise: A Bad Deal for America.” All of these, nonetheless, provided the opportunity for proponents of action to present the reality of climate change and the need for regulatory and international action. Eight other hearings questioned government science or regulatory action, with seven of them contesting ineffective regulation, costs, and alarmist manipulation of science. One avoided contestation because the stasis centered on whether investment should be made in carbon sequestration to protect coal's position in the future energy mix. As elsewhere, when climate change served economic interests, it was rarely contested. The twelve other instances where climate change was not contested were incidental or minor mentions.

In six hearings in the Appropriations Committee, however, climate change was an accepted part of the work of the agencies examined, despite passing remarks about overregulation and its costs, as in one hearing in the Agriculture Committee. In the Foreign Affairs Committee two incidental mentions were let pass with no comment. Even in the six hearings mentioning climate change in the Oversight Committee, none took on climate change regulation as a central or major issue, even when the EPA was the focus of attention; questions of overregulation or management of climate change issues came up in only 4 in passing.

So in the $114^{\text {th }}$ Congress, with the fact of climate change no longer an issue, but also no legislation likely, the Senate was largely quiescent on climate change issues, avoiding discussion, even when events such as the Paris Conference called for comment--except in one committee with a strongly oppositional chair aiming to create an oppositional record. Multiple House committees, however, widely questioned regulation, cost, and procedures to create a negative record on actions, though not on the reality of climate change. The minority could only make the case for action from the sidelines and only when the stasis created space to make the arguments. 


\subsection{The $115^{\text {th }}$ Congress (2017-Partial)}

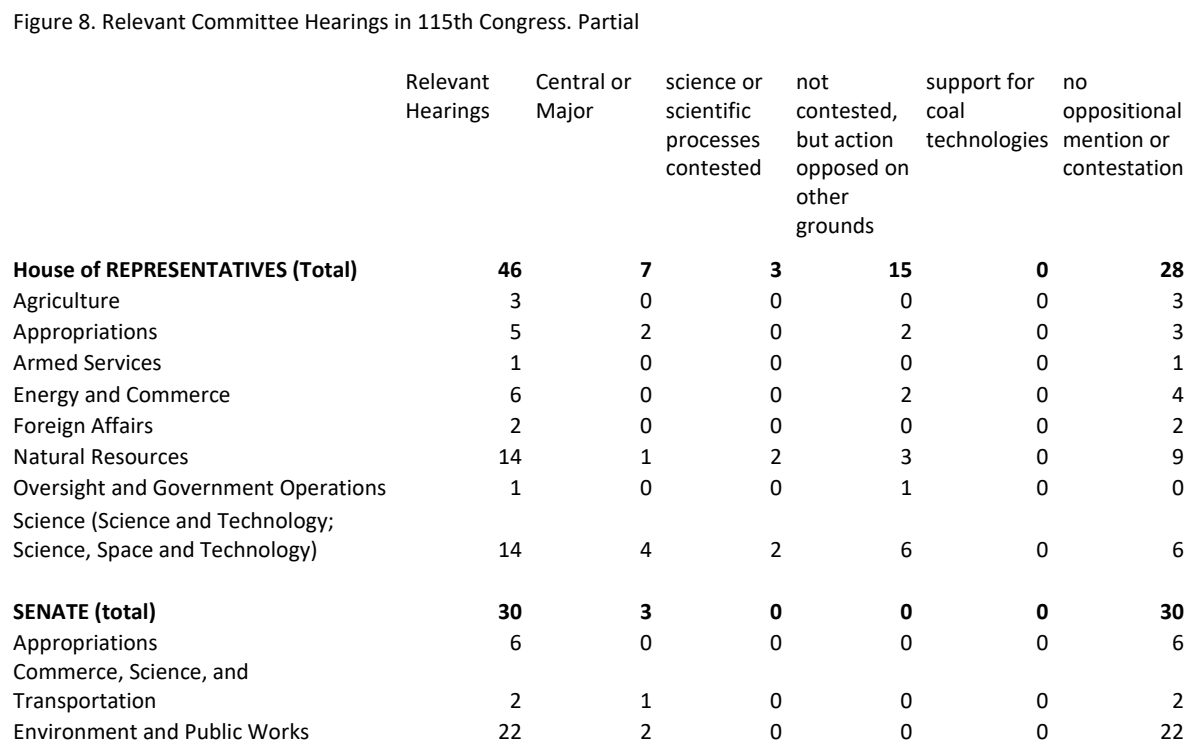

With the 2016 election of President Trump and the continuing Republican control of both houses, climate change became even less of an issue in the $115^{\text {th }}$ Congress, still in progress at the time of this writing. Trump's has stated an intention to withdraw from the Paris Agreement (Tabuchi \& Fountain, 2017), has appointed climate skeptics and opponents of regulation to head administrative agencies relevant to climate change-such as Scott Pruitt at the Environmental Protection Agency (Davenport, 2017), and has loosened environmental regulation. So the majority in Congress which already expressed no desire to act, now had little motive to investigate the executive, and therefore little need to collect facts on administrative action or inaction. On the other hand, many Majority members of Congress seemed to accept the reality of climate change, but preferred not to act or even discuss it; therefore, they had little motive to either raise or contest scientific facts. As of this writing, the record of Congressional hearings is incomplete; nonetheless, the number of hearings discussing climate change seems to have further decreased from the previous Congress with climate change taking on a more marginal role discussed. From the published hearings available in mid-February 2018, transcripts are available for only 30 relevant Senate hearings in 2017 and 46 in the House, with mentions tending to arise only in questions from the minorities or in statements of witnesses, with only rare comment by majority members of Congress.

The Senate Environment and Public Works Committee presents a striking case of the current strategy. Inhofe, having served as chair for as long as his party regula- 
tions allowed, was succeeded by Barrasso, who also had opposed action but had not opposed the science so vigorously. In the 22 hearings of this committee relevant to climate change (over 2/3 in the entire Senate during this period), climate change's reality was not contested a single time. In 16 of these, no opposition of any sort was expressed. In the nominating hearing for Scott Pruitt, minority Senators grilled him on his beliefs about Climate Change and he kept insisting he did believe in it and was at odds with President Trump on this matter. In several other nomination hearings for multiple positions, the candidates also avoided stating they opposed climate change or climate change action. Climate change was central in only two hearings, both devoted to emissions technology and the role of industry as the source for innovation and economic leadership. In both climate change was accepted as an uncontested fact. Similarly, in another hearing devoted to biofuels, climate change was an accepted assumption, and the debate was only whether corn based ethanol or other forms of biofuels were preferable.

The Senate Appropriations Committee when considering funding of agencies responsible for climate change research and action, as much as possible avoided use of directly mentioning or opposing climate change. Three of those hearings were just statements from non-governmental organizations with no Congressional questioning or response. In the three other relevant hearings, witnesses from governmental agencies in response to minority questions used evasive language, for example saying only they had an interest in climate, but not that they acted on climate change.

The Commerce Committee only had two hearings relevant to climate change, and one had only an incidental mention in a question, which evoked no opposition. The other was a field hearing in Florida looking into flooding. With only the local Senator present, no one questioned that the floods were indeed a result of climate change.

In the House the majority in most committees followed as well the strategy of not discussing climate change but not talking about it as much as possible except to consider free market and industrial solutions. In the Agriculture, Foreign Relations, and Armed Services Committees, the assumption of climate change was accepted as a relevant factor for considerations and was not contested. In the six hearings in the Energy and Commerce Committee, on one occasion the value of market-based solutions was offered and on another concerning hydropower a Senator pointed out that reservoirs also released greenhouse gases. In the five relevant hearings in the Appropriations Committee, in two hearings relief from regulation was argued, most fully in Secretary of Interior Zinke's testimony that the Paris Agreement was a bad deal, but there was no contestation of the existence of climate change or human causation. In the fourteen hearings of the Natural Resources Committee, which considered climate change as a factor, however, twice Representatives asserted that climate change was not so rapid or certain as assumed and on two other instances it was argued that specific current administration practices were effective, but the previous administration's identification of land for protection were ineffective. 
None of the 32 aforementioned hearings in all these committees had climate change as the central focus or assumption and only three placed it as a major consideration.

Only in the Science, Space, and Technology Committee did the majority take a vocal, consistent position in opposition to climate change action, attacking the scientific consensus and actions of the previous administration. In its fourteen hearings related to climate change, two made the issue central and two others treated it as a major concern. Of those, "Making the EPA Great Again" and "Climate Science: Assumptions, Policy Assumptions, Policy Implications, and the Scientific Method" presented focused attacks on the findings and methods of climate science, and government use of the findings. Another hearing questioned the costs of climate action, presenting economic evidence. Interestingly, however, a hearing on creating resiliency in the electric grid considered climate change as the major threat, with no contestation or objection. Five of the remaining hearings where climate change took a lesser role offered arguments for free market solutions or against the efficacy or appropriacy of government action, and five others offered no objections or contestations to the mention of climate change.

Overall in the first year of the $115^{\text {th }}$ Congress, all but one of the committees largely avoided discussing climate science or executive action; moreover, the questions of the minority were evaded without contestation. In fact, a number of the more extensive discussions of climate change occurred when administration witnesses were questioned by minority members and presented themselves as recognizing the problem and taking adequate, appropriate action. Only a few in the Congress or the Administration denied climate change or anthropogenesis, but action was still evaded by the dominant majority party largely by avoiding discussion or pointing to free market and technological solutions. Only the House Science, Space, and Technology Committee made climate change a contested issue.

\subsection{Discussion}

The road to understanding how Congress does or does not act on climate change has gone through understanding the genres by which knowledge is made part of the record, how these genres are produced, who controls the production, and the tools by which production is controlled. Understanding these processes and tools can, in turn, identify for us as citizens the pressure and intervention points to influence Congressional action on climate issues. While these processes and tools are endemic within Congress on many issues, the great exigency of anthropogenic climate change calls us to unpack and make more transparent previously unexamined mechanisms of collective institutional Congressional knowledge-making.

The genres of hearings transcripts record knowledge ostensibly relevant for Congressional action. These genres are shaped through the particular mechanisms, 
opportunities, and constraints of the committee processes. The record of knowledge in these genres is produced through the activities of the respective committees, under the control of the committee chair from the majority party in each house. Events and changing political alignments and agendas create opportunities for committee chairs to schedule hearings. However, which opportunities are taken up, with what stases, depend on each chair's policy commitments, political calculations, and strategies that influence the kind of record they would like created in the resulting hearing transcript.

Though purposes may be partisan and contexts change, these tools of scheduling hearings, framing stases, and inviting witnesses are shared by committee chairs of either party when they are in control to create knowledge records to serve as predicates and justifications for action, oversight, and budgeting - and accountability for reelection. Congress members may vote and act on bases other than the official knowledge, and even in contradiction to it, but these tools present what Congress officially knows within the deliberations of each term. The tools of the minority members led by their ranking member are more limited, to call the majority constructed knowledge in doubt, or perhaps just to open up a wider range of considerations. The minority can be granted witnesses, but these witnesses and their testimony must be selected within relevance to the stases established by the majority chair. The statements of the ranking member and committee members also offer space to present facts and views, again with relevance to the stases, though occasional strategic digressions are possible. Finally, the minority members can ask questions of witnesses that press them on sensitive issues, comment on difficult facts, or pose alternative positions.

Both sides attempt to create a record that gets the facts relevant to their position on the record, in order to define or diffuse a problem to be acted on (or not). The main device for creating the public record is framing the questions of the hearings on which testimony is presented and follow-up questions constrained. This device is in the hands of the chair of the majority party, and the minority party is largely limited to call into doubt the record being created by the majority's framing. In short, the majority can talk about what it wants, and the minority can only object within the limits of that discussion. While giving the appearance of deliberations, hearings currently limit discussion in the interests of the majority and limit the record of knowledge.

Casting doubt on the recorded knowledge is typically a strategy of the minority, but the majority can also adopt such a strategy when addressing consensus knowledge among significant relevant publics, such as with anthropogenic climate change over this period. As IPCC reports have become more insistent and major climate events have been widely experienced, opponents of action must narrow evidentiary doubts to the degree of human causation, the pace of change, or potential bias and scandals in science. Opponents of action also switch stases to values that are claimed to outweigh climate change, such as the costs of regulation to the economy and jobs, or the protection of particular industries. Opponents also adopt procedural stases, such as the legality of administrative actions, the extension of other laws to address climate 
change, or the appropriate jurisdictions for regulating harms. Procedures for equitable international cooperation on climate change are also regularly invoked. Even with evidentiary and value agreement on acting on climate change, the deliberative question remains of which procedure or mechanism for action should be chosen. This last stasis strongly invokes fundamental beliefs about the best ways to solve problems, whether government regulation, market mechanisms, or technological advances.

Since the 535 voting members of Congress have varying beliefs, experiences, interests to represent, and political identities within their constituencies, they may come to individual positions even when party discipline calls them to respect party positions. On each side a few individuals adopt the most vigorous public stances, often committee chairs or ranking minority members. Democrats seem to uniformly accept the need for action on climate change, even when attuned to protecting particular energy interests. Republicans, however, seem to have a spectrum of views behind the general party opposition to government regulation, but vigorous argument was largely limited to opponents of action, situated in a few committees. In other committees, Republican chairs and ranking members raise few objections to the scientific consensus, and at times announce their recognition of climate change and support action, though without extensive facts and argument. Rather they tend to remain silent or act quietly on issues before them accepting climate change assumptions. Even some Republican members of committees whose leadership express oppositional views and arrange for opposition witnesses, act in consonance with belief in climate change. Finally, when climate change is mentioned only peripherally, even vocal opponents of climate change action frequently simply say nothing.

This suggests that a bipartisan majority of both houses, no matter which party is currently in control, actually recognizes climate change and the need for action, though disagreeing on the kind of action to be taken. The Republican strategy of leaving the dominating voice to a few individuals who oppose action may even, by stalling government action, serve the interests of those who accept climate change, but believe in free market solutions and technological advances without government intervention.

Whatever may motivate the various positions, and however we may evaluate their substance, the structure of committees, hearings, and stases allow the construction of a record of knowledge that can either advance or obstruct vigorous legislative action to mitigate climate change and support for executive action through Congressional oversight, depending on the parties in control. Whether these processes are inevitable or even good, they are currently part of how Congress works or doesn't work, how it knows or avoids knowing. It all comes down to what you know depends on what you ask and whom you allow to contribute to what part of the answer. And what you ask depends on the rules of asking, the conditions that prompt the asking, and who leads the discussion. So apart what Congress members may know as individuals, Congress as an institution represents itself as knowing what its influential members and leadership want it to appear to know. 


\section{References}

Aristotle (1991). Aristotle 'On rhetoric': A theory of civic discourse. (G.A. Kennedy, Trans.). New York, NY: Oxford University Press.

Arnold, R.D. (1990). The logic of congressional action. New Haven: Yale University Press.

Bazerman, C. (1991). How natural philosophers can cooperate: The rhetorical technology of coordinated research in Joseph Priestley's History and present state of electricity. In C.

Bazerman \& J. Paradis (Eds.), Textual dynamics of the professions (13-44). Madison: University of Wisconsin Press.

Bazerman, C. (1994). Systems of genre and the enactment of social intentions. In A. Freedman \& P. Medway (Eds.), Genre and the new rhetoric (79-101). London: Taylor \& Francis.

Bazerman, C. (2009). How does science come to speak in the courts? Citations, intertexts, expert witnesses, consequential facts and reasoning. Law and Contemporary Problems, 72(1), 91-120.

Bazerman, C. (2013). A theory of literate action. Colorado Springs: WAC Clearinghouse.

Bazerman, C., \& Self, B. (2017). Writing the world to build the world, iteratively: Inscribing data and projecting new materialities in an engineering design project. In R.K. Durst, G.E. Newell \& J.D. Marshall (Eds.), English language arts research and teaching: Revisiting and extending Arthur Applebee's contributions (91-106). London: Routledge.

Burke, K. (1931). Counter statement. New York: Harcourt, Brace and Company.

Bush, G. (2007, January 23). President Bush's 2007 State of the Union Address. Washington Post. Retrieved from http://www.washingtonpost.com/wp-dyn/content/article/2007/01/23/ AR2007012301075.html.

Cicero (1949). De inventione; de optio genere oratorum; topica. Cambridge MA: Harvard University Press.

Davenport, C. (2017, March 3). E.P.A. chief doubts consensus view of climate change. The New York Times. A1. Retrieved from https://www.nytimes.com/2017/03/09/us/politics/epa-scott-pruittglobal-warming.html.

Deering, C.J., \& Smith, S. (1997). Committees in Congress. (3rd Ed.). Washington, D.C.: CQ Press.

Fahnestock, J., \& Secor, M. (1988). The stases in scientific and literary argument. Written Communication, 5(4), 427-443. doi:10.1177/0741088388005004002.

Fenno, R.F. (1973). Congressmen in committees. Boston: Little, Brown and Company.

Galloway, G.B. (1959). Development of the committee system in the House of Representatives. American Historical Review, 65(1), 17-30. doi:10.2307/1846599

Galloway, G.B. (1961). History of the House of Representatives. New York: Thomas Y. Crowell.

Greenhouse, L. (2007, April 3). Justices say E.P.A. has power to act on harmful gases. The New York Times, A1. Retrieved from http://www.nytimes.com/2007/04/03/washington/03scotus.html

Grice, P. (1975). Logic and conversation. In P. Cole \& J. Morgan (Eds.), Syntax and semantics. 3: Speech acts (41-58). New York, NY: Academic Press.

Holthaus, E. (2015, Jan 21). Senate Votes 98-1 That climate change is real but splits on that pesky cause. Slate. Retrieved from http://www.slate.com/blogs/future_tense/2015/01/21/senate_ votes_that_climate_change_is_real_but_doesn_t_agree_on_cause.html

Krehbiel, K. (1991). Information and legislative organization. Ann Arbor: University of Michigan Press.

Mann, T., \& Ornstein, N. (2006). The broken branch: How Congress is failing America and how to get it back on track. New York, NY: Oxford University Press.

Mantel, H.N. (1959). The Congressional Record: Fact or fiction of the legislative process. The Western Political Quarterly, 12(4), 981-995. doi:10.2307/443792.

Mayhew, D. (2004). Congress: The electoral connection ( $2^{\text {th }}$ ed.). New Haven: Yale University Press. 
Merton, R.K. (1973). The sociology of science: Theoretical and empirical investigation. Chicago: University of Chicago Press.

Miller, C. (1984). Genre as social action. Quarterly Journal of Speech, 70, 151-67. doi:10.1080/00335638409383686.

Miller, C., \& Selzer, J. (1985). Special topics of argument in engineering reports. In L. Odell \& D. Goswami (Eds.), Writing in non-academic settings (309-341). New York, NY: Guilford.

Nonaka, I. (1994). A dynamic theory of organizational knowledge creation. Organizational Science, 5(1), 14-37. doi:10.1287/orsc.5.1.14.

Quintillian (1920). Institution oratoria (vol. 1). Cambridge MA: Harvard University Press.

Russell, D.R. (1997). Rethinking genre in school and society: An activity theory analysis. Written Communication, 14, 504-554. doi:10.1177/0741088397014004004.

Schmeckebier, L.S. (1925). The Government Printing Office: its history, activities, and organization. Baltimore: Johns Hopkins Press.

Schmeckebier, L.S., \& Eastin, R. (1969). Government publications and their use (2 ${ }^{\text {nd }}$ rev. ed.). Washington, D.C.: Brookings Institution.

Sperber, D., \& Wilson, D. (1986). Relevance: Communication and cognition ( $2^{\text {nd }}$ ed.). Oxford: Blackwell.

Tabuchi, H., \& Fountain, H. (2017, June 1) Bucking Trump, these cities, states and companies commit to Paris Accord. The New York Times, A12. Retrieved from https://www.nytimes. com/2017/06/01/climate/american-cities-climate-standards.html.

Wawro, G.J., \& Schickler, E. (2006). Filibuster: Obstruction and lawmaking in the U.S. Senate. Princeton: Princeton University Press.

Weingast, B.R., \& Marshall, W.J. (1988). The industrial organization of Congress; or, why legislatures, like firms, are not organized as markets. Journal of Political Economy, 96(1), 132-163. 